\title{
Article \\ Nanostructured Black Nickel Coating as Replacement for Black Cr(VI) Finish
}

\author{
Marina M. Mennucci ${ }^{1, *(\mathbb{D})}$, Rodrigo Montes ${ }^{1}$, Alexandre C. Bastos ${ }^{1} \mathbb{C}$, Alcino Monteiro ${ }^{2}$, Pedro Oliveira ${ }^{2}$, \\ João Tedim ${ }^{1} \mathbb{D}$ and Mário G. S. Ferreira ${ }^{1} \mathbb{D}$ \\ 1 DEMaC - Department of Materials and Ceramic Engineering, CICECO-Aveiro Institute of Materials, \\ University of Aveiro, 3810-193 Aveiro, Portugal; rodrigomontes@ua.pt (R.M.); acbastos@ua.pt (A.C.B.); \\ joao.tedim@ua.pt (J.T.); mgferreira@ua.pt (M.G.S.F.) \\ 2 Leica-Aparelhos Ópticos de Precisão, S.A., Rua da Leica 55, 4760-810 Lousado VNF, Portugal; \\ amonteiro@leica.pt (A.M.); poliveira@leica.pt (P.O.) \\ * Correspondence: marinamennucci@ua.pt
}

check for updates

Citation: Mennucci, M.M.; Montes,

R.; Bastos, A.C.; Monteiro, A.;

Oliveira, P.; Tedim, J.; Ferreira, M.G.S

Nanostructured Black Nickel Coating as Replacement for Black Cr(VI) Finish. Appl. Sci. 2021, 11, 3924. https:// doi.org/10.3390/app11093924

Academic Editors: Alberto Milani,

Roberto Martins and Olga

Barbara Kaczerewska

Received: 30 March 2021

Accepted: 22 April 2021

Published: 26 April 2021

Publisher's Note: MDPI stays neutral with regard to jurisdictional claims in published maps and institutional affiliations.

Copyright: (c) 2021 by the authors. Licensee MDPI, Basel, Switzerland. This article is an open access article distributed under the terms and conditions of the Creative Commons Attribution (CC BY) license (https:// creativecommons.org/licenses/by/ $4.0 /)$.
Featured Application: The black coatings described in this work find application in decorative finishes, optical instruments, and photovoltaic modules.

\begin{abstract}
This work compares different electrodeposition procedures to produce nickel black coatings as greener and less toxic alternatives to $\mathrm{Cr}(\mathrm{VI})$-based coatings used in different applications. Nickel and nickel-plated brass served as substrates in studies with a Hull cell and polarization curves. After a set of comparative experiments, the best electrodeposition procedure was further studied and optimized. Optimal conditions were found with a bath consisting of $75 \mathrm{~g} / \mathrm{L} \mathrm{NiCl}_{2} \cdot 6 \mathrm{H}_{2} \mathrm{O}+30 \mathrm{~g} / \mathrm{L}$ $\mathrm{NaCl}$ and a current density of $0.143 \mathrm{~A} \mathrm{dm}^{-2}$ applied for $5 \mathrm{~min}$ at room temperature. Furthermore, a pre-treatment with $18.5 \mathrm{vol} \%$ of hydrochloric acid in water was found to be necessary to warrant good coating adhesion to the substrate. The black color is attributed to the development of a nanostructured surface that absorbs the incident light. Corrosion testing was performed in $0.5 \mathrm{M}$ $\mathrm{NaCl}$ aqueous solution using electrochemical impedance spectroscopy (EIS) and polarization tests.
\end{abstract}

Keywords: black nickel coatings; electrochemical testing; electrodeposition; hull cell; nanostructured coatings

\section{Introduction}

Black coatings are surface finishes with functional [1-10] or decorative [4,7-9] purposes. The films must satisfy characteristics such as adhesion, mechanical, and corrosion resistance. High absorbance capacity is required for solar [9] and optical applications [11,12], while decorative finishes must be resistant to wear and preserve a good and uniform appearance throughout the service life. Often these coatings are obtained by electrodeposition from hexavalent chromium baths [4,9,13-15]. Despite the good quality of chromium coatings, both health and environmental concerns associated with chromium (VI)-derived species [16-20] led to the prohibition of hexavalent chromium products [19,21] thereby forcing the industry to search for greener and safer alternatives [2,5-11,20]. The risks associated with chromium (VI) compounds [21-25] include allergic skin reactions that appear immediately after contact, regardless of the dose. Brief exposure to high concentrations can result in ulceration of the exposed skin, perforation of the respiratory tract, and irritation of the intestinal tract [16-18,21,25]. Kidney and liver damage have also been reported [16-18]. In addition, chromium (VI) compounds are classified as carcinogenic [16-18,20,21]. Prolonged occupational exposure to air with chromium levels higher than those present in the natural environment has been linked to lung cancer [16-18,21]. Workers in the chromium compounds manufacturing industry are those most at risk, but problems appear also in workers from the electroplating, metal artifacts handling, chrome alloys and stainless-steel welding, and chromium pigments industries. 
Greener and less toxic baths for electroplating black coatings based on nickel [1-10], trivalent chromium $[9,26]$, zinc $[9,27]$, phosphate $[9,28]$ and molybdenum $[9,29]$ have been proposed. Some of these coatings are nanostructured $[1,30,31]$. Other procedures to deposit black coatings include electroless deposition [9,32] and vapor phase deposition $[9,33,34]$.

Lira-Cantú et al. [1] studied the electrochemical deposition of black nickel solar absorber coatings on stainless steel AISI316L for thermal solar cells. They electrodeposited a bright nickel coating followed by a black nickel solar absorber coating and a top antireflection coating based on TEOS (tetraethyl orthosilicate). The bath solution was nickel chloride $75 \mathrm{~g} / \mathrm{L}$ and sodium chloride $30 \mathrm{~g} / \mathrm{L}$, at room temperature $\left(25-27^{\circ} \mathrm{C}\right)$. To obtain the solar absorber coating, it was necessary to apply two different current densities $\left(1.4 \mathrm{~mA} / \mathrm{cm}^{2}\right.$ and $2.6 \mathrm{~mA} / \mathrm{cm}^{2}$ ) with an intermediate drying step with nitrogen. A small modification in current density did not affect solar absorptance, but deposition time did. Times greater than $60 \mathrm{~s}$ and $90 \mathrm{~s}$ for the first and second depositions, respectively, led to high solar absorptance but poor thermal emittance. The thickness of the black nickel coating varied between 1.3 and $1.7 \mu \mathrm{m}$, depending on the deposition time. The TEOS coating improved the absorptivity value when dried at $200^{\circ} \mathrm{C}$, and decreased it when dried at $300^{\circ} \mathrm{C}$.

With the same bath composition, Wäckelgård [2] varied the deposition parameters to obtain maximum solar absorptance and minimum thermal emittance from coatings formed on aluminum or copper substrates. As aluminum is difficult to plate directly, two steps were carried out prior to the black coating deposition. First, a pretreatment with double-zincate immersion technique was applied [3], followed by a bright nickel film deposition. Two temperatures were tested, $19{ }^{\circ} \mathrm{C}$ and $25^{\circ} \mathrm{C}$, under two current regimes: $70 \mathrm{~mA} / \mathrm{dm}^{2}$ for $2-6 \mathrm{~min}+130 \mathrm{~mA} / \mathrm{dm}^{2}$ for $1-2 \mathrm{~min}$ in one case, and in another $110 \mathrm{~mA} / \mathrm{dm}^{2}$ for $3 \mathrm{~min}+220 \mathrm{~mA} / \mathrm{dm}^{2}$ for $1 \mathrm{~min}$. According to Wäckelgård [2], to achieve high solar selectivity two distinct sublayers must be present and for that, the process must be interrupted, with the sample removed from the solution and the surface dried before the second plating stage. If the sample remains in the bath, no distinct separation between the two layers is produced by the different current regimes. The top coating consisted of flakes about $200 \mathrm{~nm}$ wide and $10 \mathrm{~nm}$ thick.

Dennis and Such [4] explained that black nickel coatings have little abrasion and corrosion resistance and to improve them the deposition of the black coating must be made over an undercoat of dull or bright nickel. They also proposed two baths for producing black nickel coatings, one based on nickel sulfate and the other on nickel chloride. Both had a high amount of zinc and thiocyanate ions, which were believed to be responsible for the black color.

Ibrahim [5] modified the Watts bath by adding $\mathrm{KNO}_{3}$ and varying its concentration. The best procedure for making a highly adherent black nickel coating on steel was achieved using a solution of $0.63 \mathrm{M} \mathrm{NiSO}_{4} \cdot 6 \mathrm{H}_{2} \mathrm{O}, 0.09 \mathrm{M} \mathrm{NiCl}_{2} \cdot 6 \mathrm{H}_{2} \mathrm{O}, 0.3 \mathrm{M} \mathrm{H}_{3} \mathrm{BO}_{3}$, and $0.2 \mathrm{M}$ $\mathrm{KNO}_{3}$ at $\mathrm{pH}=4.6, \mathrm{i}=0.5 \mathrm{~A} / \mathrm{dm}^{2}, \mathrm{~T}=25^{\circ} \mathrm{C}$, and $\mathrm{t}=10 \mathrm{~min}$. Instantaneous nucleation was indicated by potentiostatic current-time transients. The black nickel coating consisted of metallic nickel with $\mathrm{Ni}(111)$ preferred orientation, as indicated by XRD studies.

Karuppiah et al. [6] produced a nickel-cobalt black coating on a copper panel precoated with a $10 \mu \mathrm{m}$ thick nickel layer applied using the Watts bath. The plating solution contained $10 \mathrm{~g} / \mathrm{L}$ of nickel sulfate, $10 \mathrm{~g} / \mathrm{L}$ of cobalt sulfate, and $10 \mathrm{~g} / \mathrm{L}$ of ammonium acetate. The solution $\mathrm{pH}$ was 6.2 at $308 \mathrm{~K}$, and the current density varied between 3 to $10 \mathrm{~A} / \mathrm{dm}^{2}$, a range obtained from Hull cell studies. Scanning electron microscopy images revealed that the deposit was constituted by particles of different sizes and shapes. Due to optical interference and surface roughness, the deposit had a high degree of solar absorption. The values of solar absorptance and thermal emittance of the coating were influenced by the deposition time and the current density.

$\mathrm{Cu}-\mathrm{Ni}$ black coatings were deposited by Aravinda et al. $[7,8]$ on molybdenum, either from an ethylenediaminetetraacetic (EDTA) complex bath solution [7] or from a triethanolamine (TEA) complex bath solution containing ammonium persulfate (AP) [8]. 
The deposits made from the EDTA solution or from the TEA solution were black, uniform, pore-free, and demonstrated good solar selectivity.

Li et al. [31] studied the electrodeposition of nanostructured black nickel thin films on brass. The plating solution was $100 \mathrm{~g} / \mathrm{L} \mathrm{NiSO}_{4} \cdot 6 \mathrm{H}_{2} \mathrm{O}+40 \mathrm{~g} / \mathrm{L} \mathrm{NiCl}_{2} \cdot 6 \mathrm{H}_{2} \mathrm{O}+30 \mathrm{~g} / \mathrm{L}$ $\mathrm{H}_{3} \mathrm{BO}_{3}$. Several parameters were analyzed in this work: current density $\left(1-5 \mathrm{~mA} / \mathrm{cm}^{2}\right)$, temperature $\left(20-80^{\circ} \mathrm{C}\right), \mathrm{pH}(2-6)$, stirring speed (200-1200 rpm), and electrodeposition time (10-60 $\mathrm{min}$ ). All parameters influenced the color of the coating, which varied between white, gray, and black, depending on the deposition conditions [31]. Varying the $\mathrm{pH}$ and keeping fixed all the other parameters $\left(60^{\circ} \mathrm{C}, 3.0 \mathrm{~mA} / \mathrm{cm}^{2}, \mathrm{t}=30 \mathrm{~min}\right.$, stirring speed $\left.=900 \mathrm{rpm}\right)$, the black color appeared with $\mathrm{pH}=2-3$, gray with $\mathrm{pH}=4$, and white with $\mathrm{pH}=5-6$. When only the current density was varied (the fixed parameters were $60^{\circ} \mathrm{C}, \mathrm{pH}=3, \mathrm{t}=30 \mathrm{~min}$, stirring speed $=900 \mathrm{rpm}$ ), the black deposit appeared with a current density of $1-3 \mathrm{~mA} / \mathrm{cm}^{2}$, gray with $4 \mathrm{~mA} / \mathrm{cm}^{2}$, and white between 5 and $6 \mathrm{~mA} / \mathrm{cm}^{2}$. When the temperature was varied, black deposits appeared only in the $60-80^{\circ} \mathrm{C}$ range. The range of stirring speed to obtain a black deposit was between 900 and $1000 \mathrm{rpm}$ [31]. It was also verified that the black nickel film possessed a nanostructure with an average grain diameter of about $50 \mathrm{~nm}$. More black coatings have been reviewed by Takadoum [9].

The present work compares electrodeposition procedures described in the literature for the production of black coatings using baths with nickel as the main metallic constituent. The objective is to select the best deposition procedure to produce black coatings on nickel substrates for decorative applications.

\section{Materials and Methods}

\subsection{Materials, Reagents, and Experimental Parameters}

A pure nickel metal sheet (99.5\% purity, $2.0 \mathrm{~mm}$ thick, Alfa Aesar/Germany) and nickel-plated brass samples (Leica/Portugal) were used as metal substrates. The nickelbased electroplating baths studied in this work are presented in Table 1 with the respective references and were prepared with pro-analysis grade reagents and distilled water.

Table 1. Deposition baths and experimental conditions for producing black nickel coatings (adapted from [9]).

\begin{tabular}{|c|c|c|c|c|c|c|}
\hline Procedure & 1 & 2 & 3 & 4 & 5 & 6 \\
\hline Reagents and Parameters & $\begin{array}{l}\text { Quantity } \\
\text { (g/L) }\end{array}$ & $\begin{array}{l}\text { Quantity } \\
(\mathrm{g} / \mathrm{L})\end{array}$ & $\begin{array}{l}\text { Quantity } \\
\text { (M) }\end{array}$ & $\begin{array}{l}\text { Quantity } \\
(\mathrm{g} / \mathrm{L})\end{array}$ & $\begin{array}{l}\text { Quantity } \\
\text { (g/L) }\end{array}$ & $\begin{array}{l}\text { Quantity } \\
(\mathrm{g} / \mathrm{L})\end{array}$ \\
\hline $\mathrm{NiSO}_{4} \cdot 6 \mathrm{H}_{2} \mathrm{O}$ & & & 0.63 & 10 & & 20 \\
\hline $\mathrm{NiCl}_{2} \cdot 6 \mathrm{H}_{2} \mathrm{O}$ & 75 & 75 & 0.09 & & & \\
\hline $\mathrm{H}_{3} \mathrm{BO}_{3}$ & & & 0.3 & & 10 & 10 \\
\hline $\mathrm{KNO}_{3}$ & & & 0.2 & & & \\
\hline $\mathrm{NaCl}$ & 30 & & & & & \\
\hline $\mathrm{NH}_{4} \mathrm{Cl}$ & & 30 & & & & \\
\hline $\mathrm{ZnCl}_{2}$ & & 30 & & & & \\
\hline $\mathrm{NaSCN}$ & & 15 & & & & \\
\hline $\mathrm{CoSO}_{4}$ & & & & 10 & & \\
\hline $\mathrm{CH}_{3} \mathrm{COONH}_{4}$ & & & & 10 & & \\
\hline EDTA & & & & & 2.5 & \\
\hline$\left(\mathrm{NH}_{4}\right)_{2} \mathrm{Ni}\left(\mathrm{SO}_{4}\right)_{2} \cdot 6 \mathrm{H}_{2} \mathrm{O}$ & & & & & 20 & \\
\hline $\mathrm{Cu}\left(\mathrm{NO}_{3}\right)_{2}$ & & & & & 2.5 & \\
\hline $\mathrm{CuSO}_{4} \cdot 5 \mathrm{H}_{2} \mathrm{O}$ & & & & & & 20 \\
\hline$\left(\mathrm{NH}_{4}\right)_{2} \mathrm{~S}_{2} \mathrm{O}_{8}$ & & & & & & 10 \\
\hline$\left(\mathrm{HOCH}_{2} \mathrm{CH}_{2}\right)_{3} \mathrm{~N}$ & & & & & & $20 \mathrm{~mL} / \mathrm{L}$ \\
\hline $\mathrm{pH}$ & & $3.5-5.5$ & 4.6 & 6.2 & 5.2 & 5 \\
\hline Temperature $\left({ }^{\circ} \mathrm{C}\right)$ & $25-27$ & Room & 25 & 35 & 27 & 27 \\
\hline $\begin{array}{l}\text { Current density } \\
\left(\mathrm{A} / \mathrm{dm}^{2}\right)\end{array}$ & $0.14(90 \mathrm{~s})+$ & 0.15 & 0.5 & $3-10$ & 0.5 & 0.5 \\
\hline Duration & & $30 \mathrm{~min}$ & $10 \mathrm{~min}$ & $5-50 \mathrm{~s}$ & $30 \mathrm{~s}$ & $30 \mathrm{~s}$ \\
\hline Reference & [1] & [4] & [5] & [6] & {$[7]$} & [8] \\
\hline
\end{tabular}




\subsection{Electrodeposition}

The black coating deposition took place in $10.5 \times 15.5 \times 10 \mathrm{~cm}^{3}$ polyethylene containers with nickel-plated brass samples as cathodes (circular shape, $3 \mathrm{~cm}$ diameter, $1 \mathrm{~mm}$ thick sheet) and pure nickel anodes (anode/cathode area ratio of 1/1.5), using a Keysight N 5751A (USA) power supply and the experimental conditions presented in Table 1 . Tests were also carried out in a Hull cell (Figure 1) $[35,36]$ with a pure Ni anode and a pure nickel plate $\left(0.2 \times 10 \times 7 \mathrm{~cm}^{3}\right)$ as cathode, following the DIN 50,957 standard [35]. The coatings adhesion to the substrate was evaluated with the cross-cut test ISO 2409:2007-08 [37]. The coating surface morphology was characterized by scanning electron microscopy using a Hitachi SU70 (Japan) microscope with an electron beam energy of 15 or $25 \mathrm{keV}$.

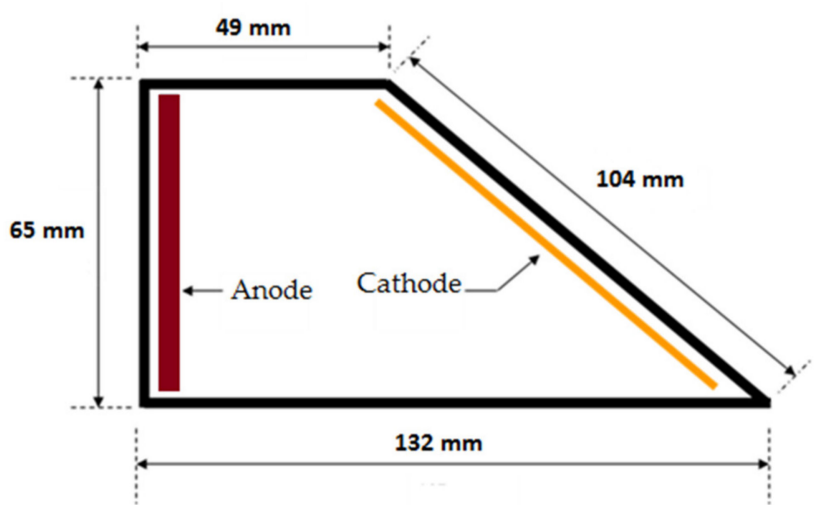

Figure 1. Top view of the $250 \mathrm{~mL}$ Hull cell used in this study.

The electrodeposition process was further investigated by polarization curves measured with an Autolab PGSTAT204 potentiostat (The Netherlands) controlled by the Nova 2.1.4 software, in an electrochemical cell with a three-electrode arrangement, comprising $1 \mathrm{~cm}^{2}$ pure Ni samples as working electrodes, a RedRod reference electrode (Radiometer Analytical REF201/Villeurbanne Cedex-France), $199 \mathrm{mV}$ vs. SHE at $25^{\circ} \mathrm{C}$ ) and a platinum wire as the auxiliary electrode. The polarization curves were obtained by sweeping the potential from $+0.1 \mathrm{~V}$ vs. OCP (open circuit potential) down to $-1.3 \mathrm{~V}$ vs. Red Rod at a scan rate of $0.5 \mathrm{mV} / \mathrm{s}$. The polarization tests were carried out in triplicate to evaluate the reproducibility of the tests.

\subsection{Corrosion Testing}

The corrosion resistance was studied by electrochemical techniques. The electrochemical cell was made by gluing polymethylmethacrylate tubes to the sample surface with epoxy adhesive. This delimited a working electrode area of $2 \mathrm{~cm}^{2}$ at the bottom of the tube and the reference and auxiliary electrodes were placed inside the tube. The testing solution was $0.5 \mathrm{M} \mathrm{NaCl}$. Electrochemical impedance spectroscopy (EIS) diagrams were obtained with a Gamry Reference 600 (USA) in potentiostatic mode at OCP, applying an ac perturbation amplitude of $10 \mathrm{mV}$ (rms) in the frequency range $100 \mathrm{kHz}$ to $1 \mathrm{mHz}$, with 10 points per decade. The reference electrode was the RedRod from Radiometer (Villeurbanne Cedex, France) and the auxiliary electrode was a coiled platinum wire. Polarization curves were measured with the same electrochemical cell arrangement but using an Autolab PGSTAT204 (Utrecht, The Netherlands) potentiostat and a saturated calomel electrode (SCE-Radiometer Analytical/ Villeurbanne Cedex-France) as reference. The potential sweeps were performed in the anodic direction, from $-0.1 \mathrm{~V} v \mathrm{vs}$. OCP to $+1.0 \mathrm{~V}_{\mathrm{SCE}}$, at a scan rate of $1 \mathrm{mV} / \mathrm{s}$. 


\section{Results and Discussion}

\subsection{Coatings Produced According to the Experimental Conditions Described in the Literature}

As stated above, the objective of this work was to select a procedure to produce a nickel black coating for decorative applications that could replace the $\mathrm{Cr}(\mathrm{VI})$ traditional one. The first step was to compare the coatings produced by directly following the procedures reported in a selection of references from the literature [1-9], as depicted in Table 1. Figure 2 shows optical images of the samples after electrodeposition. The sample presented in Figure 2a shows the substrate before deposition. Figure $2 \mathrm{~b}$ corresponds to the sample treated according to procedure 1 , in which a black matte coating was deposited. Samples presented in Figure 2c, Figure 2d were obtained following procedures 2 and 3 respectively, but in these cases, the deposition attempts were not successful. On the other hand, procedure 4 produced pulverulent black deposits with current densities of $5 \mathrm{~A} / \mathrm{dm}^{2}$ (Figure 2e) and $3.57 \mathrm{~A} / \mathrm{dm}^{2}$ (Figure 2f). No deposition was observed with procedure 5 (Figure $2 \mathrm{~g}$ ) while procedure 6 produced a non-uniform grayish to brownish deposit (Figure $2 \mathrm{~h}$ ). The discrepant results could be a consequence of using a substrate and /or cell geometry different from those established in the reference works. A direct application of the original experimental parameters is unlikely to be successful. It is evident that the experimental parameters must be modified to produce a black coating and then optimized for obtaining the desired finish quality.

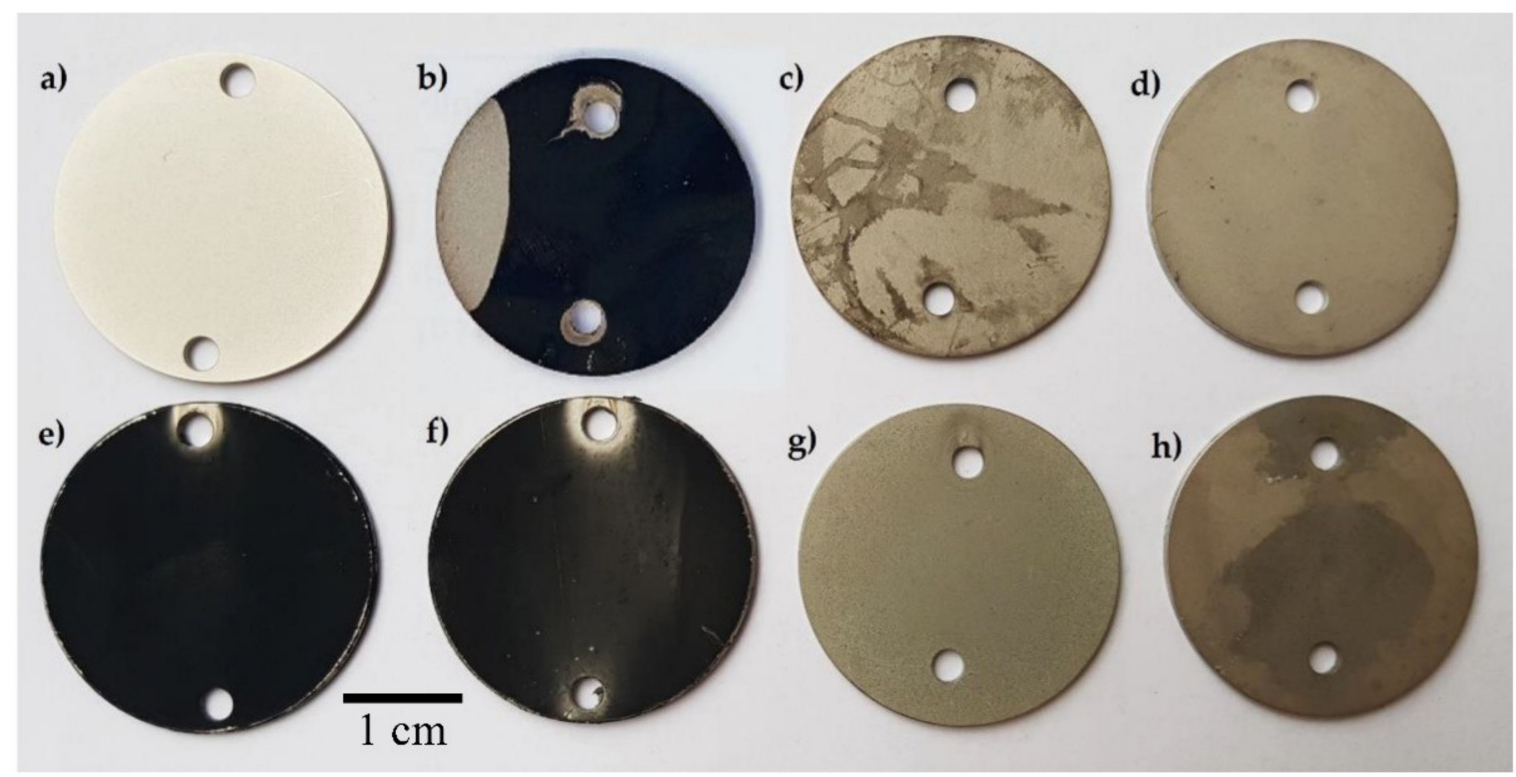

Figure 2. Nickel-plated brass samples after black coating deposition following the procedures in Table 1. (a) sample before deposition (substrate), (b) procedure 1, (c) procedure 2, (d) procedure 3, (e,f) procedure 4, (g) procedure 5, (h) procedure 6.

\subsection{Tests Using the Hull Cell}

Among the several parameters that influence coating deposition, the current density is probably the most determinant. In this work, a Hull cell was used to find the optimal range of current density for the formation of a black deposit. This small-scale electrodeposition tank has a trapezoidal shape to create a varying distance between the anode and cathodeFigure 1-thus making it possible to analyze a wide range of current densities in a single experiment. The Hull cell allows studying the relationship between current density and the quality of the deposited metallic layer varying the plating conditions, as for example bath constituents, temperature, agitation, among others [14,15]. In a $250 \mathrm{~mL}$ Hull cell like the one used in this work, the current density distribution on the cathode surface cell can be calculated by Equation (1) [35]:

$$
i=I(5.10-5.24 \log \mathrm{d} x)
$$


where $i$ is the current density $\left(\mathrm{A} / \mathrm{dm}^{2}\right)$ at point $x, I$ is the current passing in the cell (A), and $\mathrm{d} x$ is the distance $(\mathrm{cm})$ between point $\mathrm{x}$ and the edge of the cathode that is closer to the anode.

Figure 3 shows the Ni plates resulting from the tests in the Hull cell using the baths of Table 1. The range of current densities where a black deposit was formed is presented in Table 2.

a)

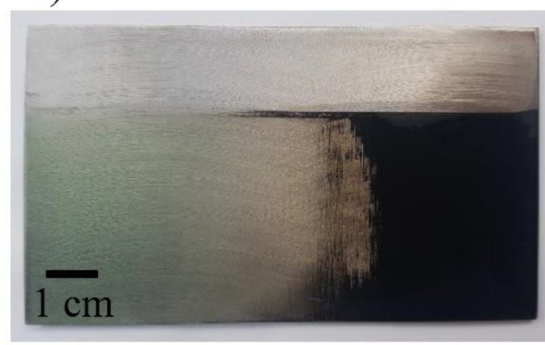

d)

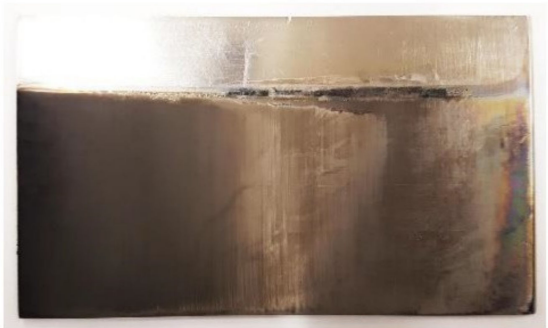

b)

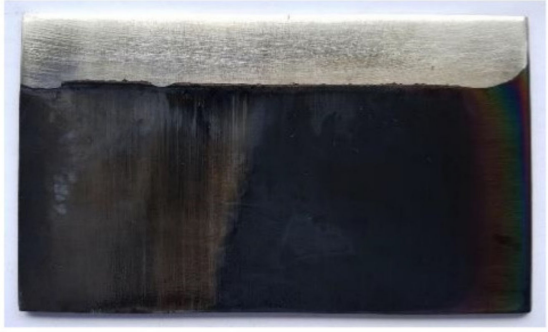

e)

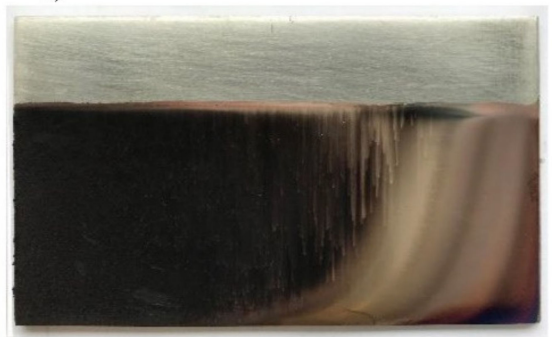

c)

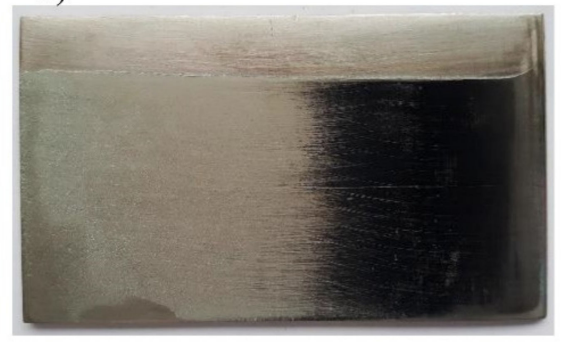

f)

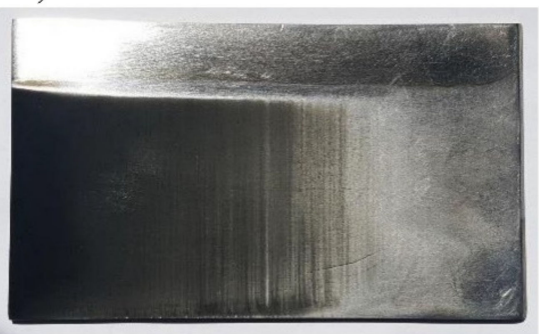

Figure 3. Hull cell samples for baths from Table 1: (a) bath 1, (b) bath 2, (c) bath 3, (d) bath 4, (e) bath 5, (f) bath 6 . The higher current density was applied on to the left side of each plate.

Table 2. Hull cell results.

\begin{tabular}{ccc}
\hline System & $\begin{array}{c}\text { Applied Current } \\
\text { (A) }\end{array}$ & $\begin{array}{c}\text { Intervals of Current Density for Black Coatings } \\
\left(\mathbf{A} / \mathbf{d m}^{\mathbf{2}}\right)\end{array}$ \\
\hline 1 & 0.5 & $0.01-0.34$ \\
2 & 1 & $0.37-0.84$ \\
3 & 1 & $0.37-0.67$ \\
4 & 1 & $4.2-20.8$ \\
5 & 2 & $10.2-41.6$ \\
6 & 1 & $3.5-20.8$ \\
\hline
\end{tabular}

In previous works, bath 1 was used for depositing black coatings on AISI 316L stainless steel [1], and on aluminum and copper [2]. In those works, a thin layer of Ni was deposited before the black coating, which means that the black deposit was, in fact, applied to a $\mathrm{Ni}$ surface. This can explain the successful deposition observed in Figure $2 b$. Previously, the black deposit was formed with current densities ranging from $0.07 \mathrm{~A} / \mathrm{dm}^{2}$ to $0.26 \mathrm{~A} / \mathrm{dm}^{2}$, sometimes in two current steps [1,2]. Here, the electrodeposition in the Hull cell was done in just one step and the black deposit appeared in the range $0.01-0.34 \mathrm{~A} / \mathrm{dm}^{2}$ (Table 2). The coating presented a black matte appearance, but it was completely removed by the adhesive tape during the cross-cut test.

Regarding bath 2, in the first set of experiments, the application of the recommended $0.15 \mathrm{~A} / \mathrm{dm}^{2}$ (Table 1) [4] did not produce the black color. In the Hull cell, a black deposit appeared for current densities between 0.37 and $0.84 \mathrm{~A} / \mathrm{dm}^{2}$ (Table 2). However, it was powdery and not adherent. In bath 3, no deposition was observed in the first set of experiments. In the original work, the substrate was steel, which may explain the result. In the Hull cell, an adherent and non-uniform blackish deposit occurred between $0.37 \mathrm{~A} / \mathrm{dm}^{2}$ and $0.67 \mathrm{~A} / \mathrm{dm}^{2}$. With bath 4 , a dark deposit appeared in the range between 4.2 and 
20.8 A/ $\mathrm{dm}^{2}$ (Table 2). The deposit was brown-reddish, loose, and powdery. Bath 5 produced a black deposit, but high current densities were needed, between $10.2 \mathrm{~A} / \mathrm{dm}^{2}$ and $41.6 \mathrm{~A} / \mathrm{dm}^{2}$, very distant from literature value, $0.5 \mathrm{~A} / \mathrm{dm}^{2}$ [7]. The deposit was powdery and loose. The color was brown-reddish for lower current densities. Bath 6 showed results similar to bath 5 , that is, a black deposit was formed at current densities in the interval 3.5-20.1 A $/ \mathrm{dm}^{2}$, much higher than the $0.5 \mathrm{~A} / \mathrm{dm}^{2}$ referred to in literature [8] and it was also powdery and non-adherent. The black coatings in references $[7,8]$ were originally applied to molybdenum. This might explain the differences with respect to the present work. The results confirm the need to modify the original procedures considering the substrate, the particularities of the deposition cell, and the properties expected for the applied coating.

\subsection{Polarization Curves}

To get more insights into the electrodeposition process, cathodic polarization curves were measured on pure nickel electrodes immersed in each of the baths. All electrochemical measurements were carried out in triplicate to evaluate the reproducibility of the tests. The curves are presented in Figure 4 and the samples after the tests are shown in Figure 5. The surfaces from baths 1, 4, and 6 (Figure 5a, Figure 5d, and Figure 5f, respectively) presented black deposits while the others (Figure $5 b$, Figure $5 c$, and Figure 5 e, respectively) were gray or dark gray. Only bath 1 (Figure 5a), however, produced a compact and adherent black coating. The samples from baths 4 and 6 (Figures $5 \mathrm{~d}$ and $5 \mathrm{f}$, respectively) were powdery. After the powder was removed the surface was still blackish.

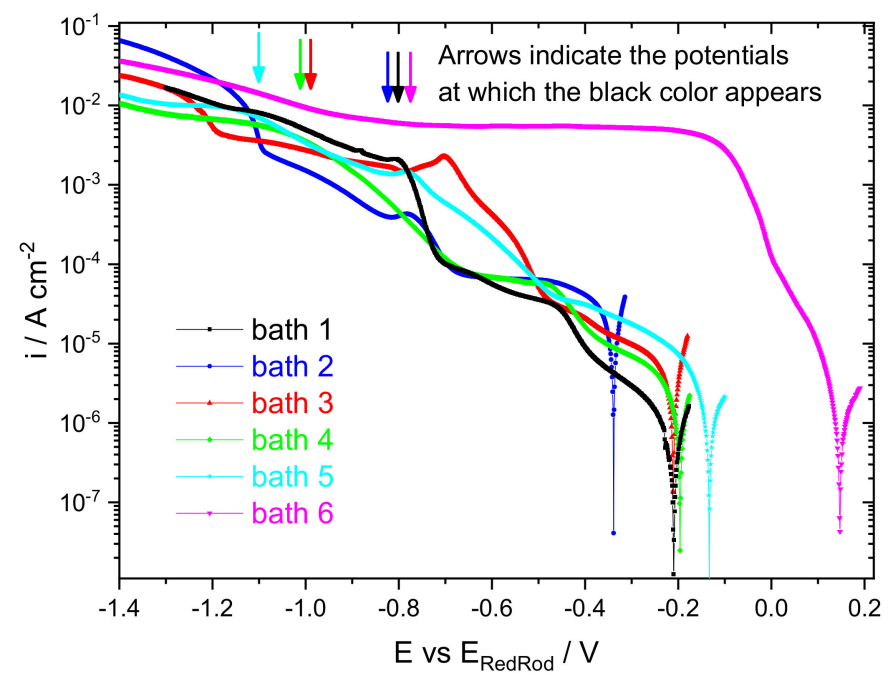

Figure 4. Polarization curves of $\mathrm{Ni}$ in the bath solutions presented in Table 1.
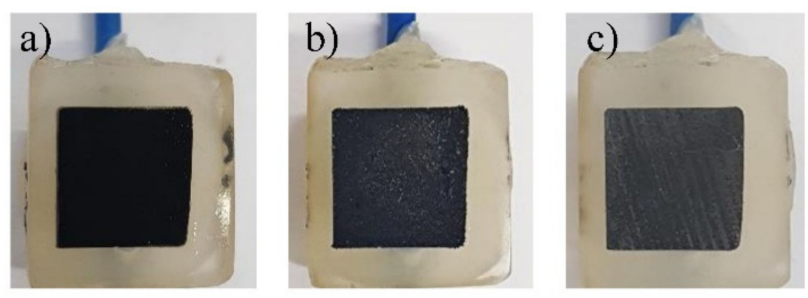

d)

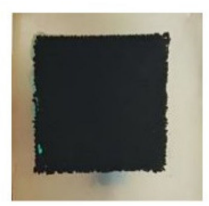

e)

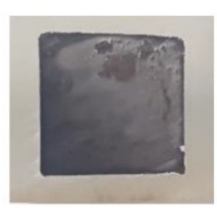

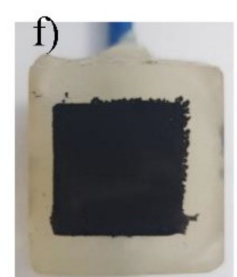

Figure 5. Ni samples $\left(1 \times 1 \mathrm{~cm}^{2}\right.$, embedded in insulating epoxy matrix) after polarization tests in: (a) bath 1 , (b) bath 2 , (c) bath 3 , (d) bath 4 , (e) bath 5, (f) bath 6 .

The curves help identify the reactions occurring at the cathode during the electrodeposition. The potentials at which the nickel surface changed color were visually perceived and are indicated with arrows in Figure 4 and the values are presented in Table 3. 
Table 3. Potential at which the surface became dark.

\begin{tabular}{cc}
\hline Solution & Potential $\left(\mathbf{V}_{\text {RedRod }}\right)$ \\
\hline 1 & -0.8 \\
2 & -0.8 \\
3 & -1.1 \\
4 & -1.0 \\
5 & -1.1 \\
6 & -0.8 \\
\hline
\end{tabular}

The open-circuit potential of nickel in baths 1,3 , and 4 was $-0.2 \mathrm{~V}_{\text {RedRod, slightly }}$ more negative in bath 2 , and slightly more positive in bath 5 . The potential in bath 6 was far more positive, probably due to the higher amount of cupric and persulfate ions. In this bath, upon the starting of the cathodic sweep, the reduction current increased rapidly and attained a limiting plateau around $10^{-2} \mathrm{~A} / \mathrm{cm}^{2}$, attributed to the reduction of $\mathrm{Cu}^{2+}(\mathrm{aq})$. Near $-0.8 \mathrm{~V}_{\text {RedRod }}$ the current increased again due to the deposition of $\mathrm{Ni}$ and is where the dark color was formed. The curves measured in baths 1,2 , and 4 , showed a current plateau of $40-60 \mu \mathrm{A} \mathrm{cm}^{-2}$ in the potential range between $-0.4 \mathrm{~V}_{\text {RedRod }}$ and $-0.6 \mathrm{~V}_{\text {RedRod }}$ due to the reduction of dissolved oxygen. Then, for potentials more negative than $-0.7 \mathrm{~V}_{\text {RedRod, }}$ the current increased and a new plateau was attained at $-0.8 \mathrm{~V}_{\text {RedRod. }}$. This increase was attributed to the deposition of metallic Ni. In baths 3 and 5, the increase in current started at less negative potentials, around $-0.45 \mathrm{~V}_{\text {RedRod }}$. The oxygen reduction still took place, but its current was too small compared to that of the metal deposition. A final increase in current at potentials more negative than $-1.1 \mathrm{~V}_{\text {RedRod }}$ was due to the hydrogen reduction reaction, with $\mathrm{H}_{2}(\mathrm{~g})$ evolution.

\subsection{Optimization of the Deposition Procedure}

In this work, most of the procedures indicated in Table 1 were unable to produce a compact, adherent, black coating. The changes in substrate and cell geometry require modifications in the deposition parameters to obtain the same black coatings reported in the original works. This optimization step could be applied to any of the procedures in Table 1 but it was decided to proceed only with procedure 1 because it produced the best coating in the previous sets of experiments, apart from having a simple and cheap bath composition and requiring low current density. The main problem detected with procedure 1 was the lack of adhesion during the cross-cut test in which the film was totally detached from the surface. A possible reason is that the film was deposited on the passive layer of the substrate and not directly on its pre-existent Ni player. To solve the problem, the samples were immersed in $18.5 \mathrm{vol} \% \mathrm{HCl}$ for $15 \mathrm{~min}$ immediately before the electrodeposition to etch the surface and activate it. The bath composition was as in Table 1 $\left(75 \mathrm{~g} / \mathrm{L} \mathrm{NiCl}{ }_{2} \cdot 6 \mathrm{H}_{2} \mathrm{O}+30 \mathrm{~g} / \mathrm{L} \mathrm{NaCl}\right)$ and the electrodeposition took place in just one step, with a current density of $0.143 \mathrm{~A} \mathrm{dm}^{-2}$, applied during $5 \mathrm{~min}$ at room temperature $\left(\sim 23^{\circ} \mathrm{C}\right)$. The anodic to cathodic area ratio was $\mathrm{A}_{\mathrm{an}}: \mathrm{A}_{\mathrm{cat}}=1 / 1.5$. The result is shown in Figure 6. The electrodeposit had a minor pulverulence on the top which, once removed with soft tissue, left a black adherent and compact film.

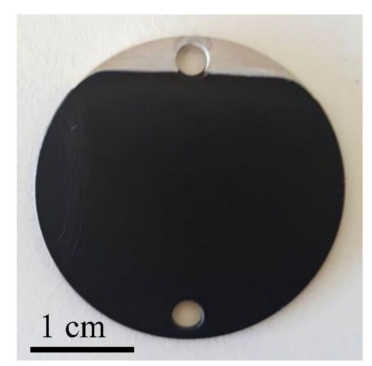

Figure 6. Nickel-plated brass sample with black nickel coating deposited from the optimized procedure 1. 


\subsection{SEM Images}

The morphology of the coating obtained by SEM is presented in Figure 7, with the substrate before deposition (Figure 7a) and the black electrodeposit with the optimized procedure at different magnifications (Figure $7 \mathrm{~b}-\mathrm{d}$ ). It is evident that the coating follows the substrate grain morphology and this is an indication of its thinness. A sub-micron to nanosized structure with nanoflakes is easily observed (Figure 7d). The optical interference by the surface roughness can be advanced as the reason for the black color of the coating $[6,30,38]$.
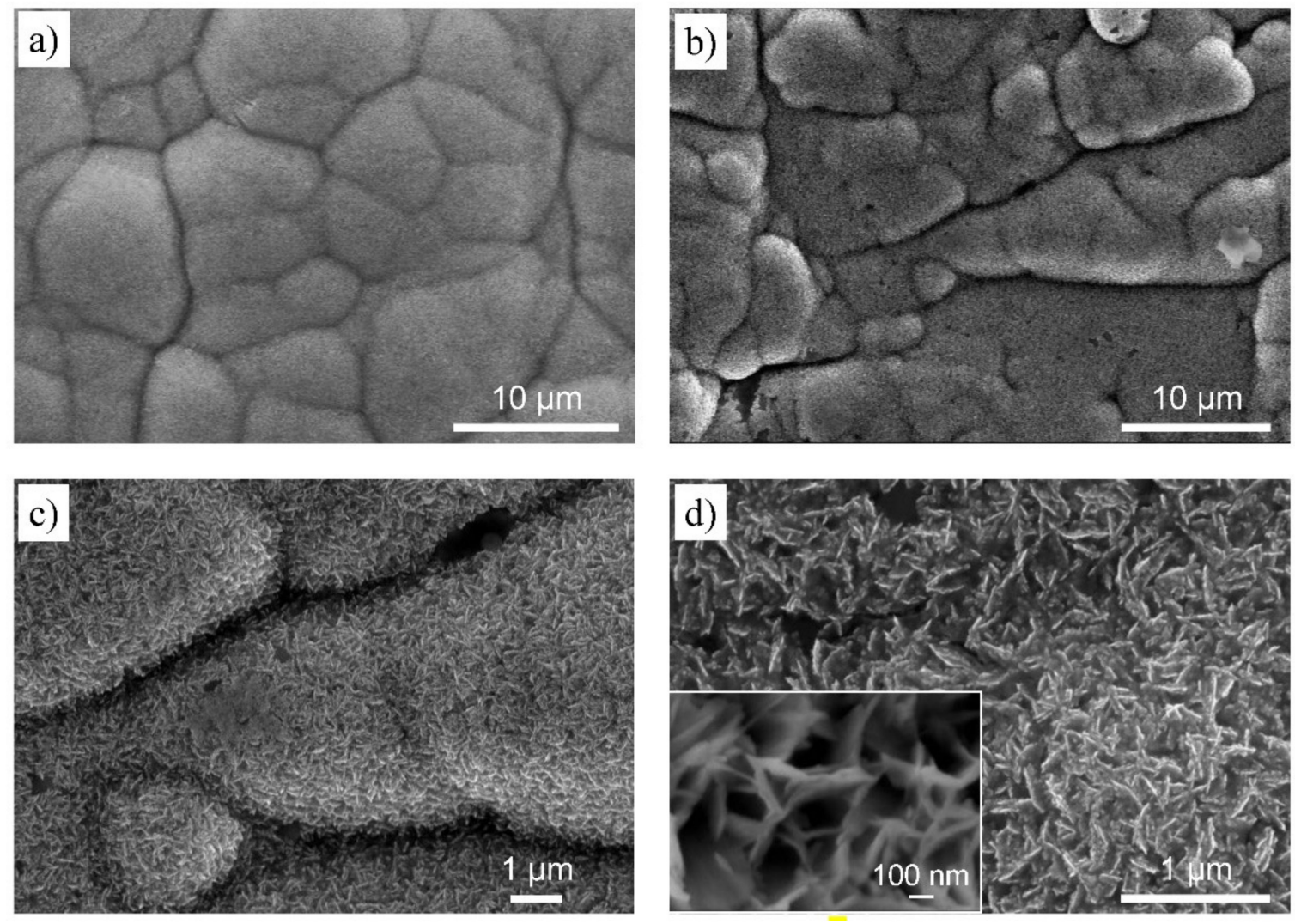

Figure 7. SEM images of the (a) nickel surface before deposition, (b-d) after deposition with the black coating at different magnifications, (d) nanostructured surface responsible for the black color.

\subsection{Corrosion Testing in $0.5 \mathrm{M} \mathrm{NaCl}$}

The corrosion resistance of the new coating was tested in $0.5 \mathrm{M} \mathrm{NaCl}$ and compared with the Ni bare substrate. All electrochemical measurements were carried out in triplicate to evaluate the reproducibility of the tests. Figure 8a shows the polarization curves measured after $2 \mathrm{~h}$ of immersion. The shapes of both curves are not very different, with similar corrosion potential, $E_{\text {corr }}$, and a quasi-passive region with a high slope, $\beta_{a}$, which means that the metal oxidation will take place with difficulty as the potential increases. The corrosion current rates, $\mathrm{i}_{\mathrm{corr}}$, were obtained by the Tafel extrapolation method (using the linear region between -0.125 and $0 \mathrm{~V}$ for the Ni sample and -0.025 and $0.1 \mathrm{~V}$ for the black $\mathrm{Ni}$ sample) and are presented in Table 4 . The curves are shifted in the current coordinates, and $i_{\text {corr }}$ is higher in the black coating but this may be due to the high roughness of the surface, which makes the real area higher than the geometric area (the one corresponding to the $2 \mathrm{~cm}^{2}$ of the working electrode). Admitting that the surface material is the same (nickel) then the reaction rate is the same and the variations in the measured current are just a consequence of the different areas. Based on this assumption, the ratio of $\mathrm{i}_{\text {corr }}$ on the coated and bare samples means that the geometric area of the black surface is around 11 times larger than the bare surface. 
a)

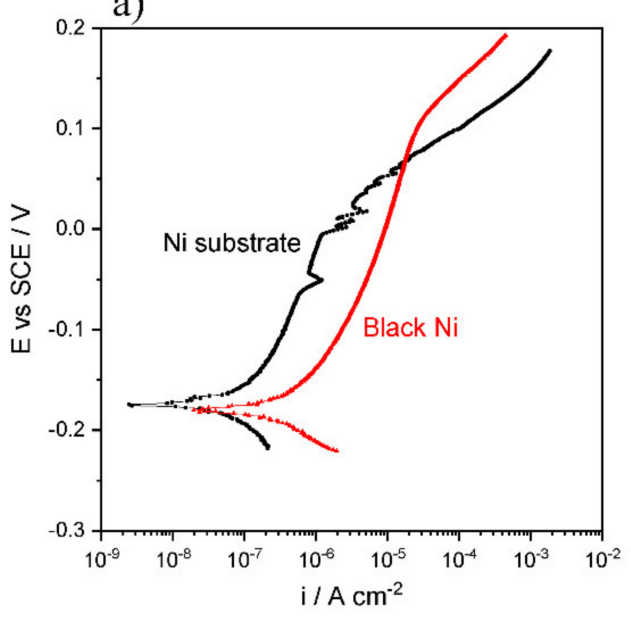

b)

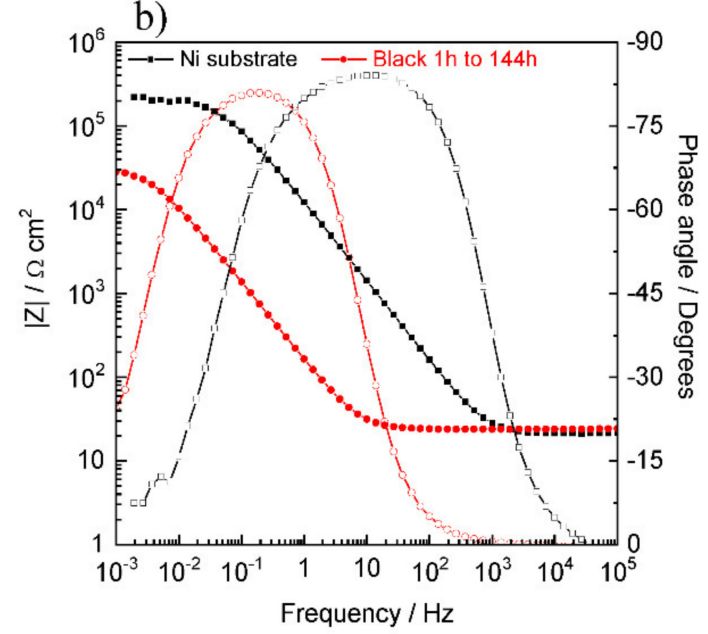

Figure 8. (a) Polarization curves measured after $2 \mathrm{~h}$ of immersion in $0.5 \mathrm{M} \mathrm{NaCl}$; (b) Bode diagrams of the impedance measured after $4 \mathrm{~h}$ of immersion in $0.5 \mathrm{M} \mathrm{NaCl}$. Spectra measured on the sample with black coating after $1 \mathrm{~h}, 120 \mathrm{~h}$, and $144 \mathrm{~h}$ of immersion were identical to the spectrum after $4 \mathrm{~h}$ shown here.

Table 4. Parameters obtained from the polarization curves in Figure 8a.

\begin{tabular}{ccccc}
\hline Sample & $\mathbf{E}_{\text {corr }}\left(\mathbf{V}_{\text {SCE }}\right)$ & $\boldsymbol{\beta}_{\mathbf{a}}\left(\mathbf{m V ~ d e c}^{-\mathbf{1}}\right)$ & $\mathbf{i}_{\text {corr }}\left(\mathbf{A ~ c m}^{-2}\right)$ & $\begin{array}{c}\mathbf{i}_{\text {corr }}(\boldsymbol{\mu m} \\
\left.\text { year }^{-\mathbf{1}}\right)\end{array}$ \\
\hline Ni substrate & -0.174 & 180.2 & $1.3 \times 10^{-7}$ & 1.4 \\
Black Ni & --0.182 & 212.3 & $1.5 \times 10^{-6}$ & 16 \\
\hline
\end{tabular}

Considering uniform dissolution, the $\mathrm{i}_{\text {corr }}$ values determined by Tafel extrapolation can be converted to penetration rate $(P R)$, using Equation (2)

$$
P R=\frac{i_{\text {corr }} M_{N i}}{n F d_{N i}} \cdot\left(3.15 \times 10^{11}\right)
$$

where $i_{\text {corr }}$ is the corrosion current density $\left(\mathrm{A} \mathrm{cm}^{-2}\right), M_{N i}$ is the Ni molar weight $\left(58.693 \mathrm{~g} \mathrm{~mol}^{-1}\right)$, $n$ is the number of electrons involved in the oxidation reaction ( 2 in this case), $F$ is the Faraday constant $\left(96,485 \mathrm{C} \mathrm{mol}^{-1}\right), d_{\mathrm{Ni}}$ is the Ni density $\left(\mathrm{g} \mathrm{cm}^{-3}\right)$ of the metal, and $3.15 \times 10^{11}$ is the conversion factor of year in seconds and $\mathrm{cm}$ in $\mu \mathrm{m}$. The values are presented in Table 4 and show small corrosion rates, higher for the black coating probably due to the area effect. These corrosion rates are just indicative because two assumptions were made in their determination: uniform corrosion and Tafel extrapolation technique valid for these results.

The impedance response of both samples is presented in Figure $8 \mathrm{~b}$ with Bode plots of EIS the spectra measured after $4 \mathrm{~h}$ in $0.5 \mathrm{M} \mathrm{NaCl}$. It is important to refer that the spectra of the black coating measured after $1 \mathrm{~h}, 120 \mathrm{~h}$, and $144 \mathrm{~h}$ did not change with respect to the one shown in Figure 8b, which demonstrates its stability.

In these experiments, the $\mathrm{Ni}$ substrate presented the highest impedance, with the response of the solution resistance at high frequencies down to $3 \mathrm{kHz}$, a capacitive response of either a passive film or the double layer capacitance, between $3 \mathrm{kHz}$ and $20 \mathrm{mHz}$ and finally, for low frequencies, a resistive response of about $200 \mathrm{k} \Omega \mathrm{cm}^{2}$, attributed to the charge transfer resistance. The black nickel sample showed a similar spectrum but with smaller charge transfer resistance and higher capacitance. These differences can be explained by the higher surface area of the black coating (not considered in the data treatment which uses the geometric area of the working electrode).

The spectra were fitted with the ZView program from Scribner Associates (USA) and the fitting parameters are presented in Table 5. The electric circuit comprised a simple $R_{s}\left(C_{d l} R_{c t}\right)$ circuit where $R_{s}$ is the solution resistance, $C_{d l}$ is the double layer capacitance and $R_{c t}$ is the charge transfer resistance. Constant phase elements (CPE) were used instead 
of capacitances, due to the non-ideal capacitive behavior of the surface [39]. The fitted parameters confirm the qualitative description presented above. In the black nickel sample the $R_{\mathrm{ct}}$ was 6 times lower and $Y_{0, \mathrm{dl}}$ was 5.5 times higher than the same values found in the Ni sample. If the real area of the black nickel sample were taken into account, the resistance would increase, and the capacitance would decrease to values close to the Ni substrate. Then, their corrosion resistances would be similar.

Table 5. Parameters obtained from the impedance spectra in Figure 8b.

\begin{tabular}{cccccc}
\hline Sample & $\mathbf{R}_{\mathbf{s}}\left(\boldsymbol{\Omega} \mathbf{c m}^{\mathbf{2}}\right)$ & $\begin{array}{c}\mathbf{Y}_{\mathbf{0} \mathbf{d l} \mathbf{l}}\left(\boldsymbol{\Omega}^{-\mathbf{1}} \mathbf{s}^{\mathbf{n}}\right. \\
\left.\mathbf{c m}^{-2}\right)\end{array}$ & $\mathbf{n}_{\mathrm{dl}}$ & $\mathbf{R}_{\mathbf{c t}}\left(\boldsymbol{\Omega} \mathbf{c m}^{\mathbf{2}}\right)$ & $\mathbf{1 0}^{\mathbf{4}} \chi^{\mathbf{2}}$ \\
\hline Ni substrate & 21.0 & $1.51 \times 10^{-5}$ & 0.937 & $2.08 \times 10^{5}$ & 11 \\
Black Ni & 22.4 & $8.34 \times 10^{-5}$ & 0.933 & $3.32 \times 10^{4}$ & 3.8 \\
\hline
\end{tabular}

\section{Conclusions}

In this work, six different electrodeposition procedures for producing nickel black coatings were compared. It was verified that the direct application of the conditions reported in the literature either did not produce any deposit or produced pulverulent and loose deposits. In one case a compact black coating was deposited but the adhesion to the substrate was poor. It became evident that the results could be due to the change in substrate and cell geometry with respect to the original works. Hull cell experiments identified ranges where all procedures were able to produce black deposits. Still, it was clear that optimization was needed to produce a coating with the desired finish quality regarding color, compactness, and adhesion. Work progressed with the procedure that gave the best results, and the final optimal conditions were found with a bath consisting of $75 \mathrm{~g} / \mathrm{L} \mathrm{NiCl}_{2} \cdot 6 \mathrm{H}_{2} \mathrm{O}+30 \mathrm{~g} / \mathrm{L}$ $\mathrm{NaCl}$, a current density of $0.143 \mathrm{~A} / \mathrm{dm}^{2}$ for 5 min of deposition at room temperature. Immediately before the electrodeposition, an acid pretreatment was necessary to warrant adhesion to the substrate. The black surface showed microroughness with nanoflakes. The black color of the coating was attributed to the optical interference caused by the surface texture. Polarization curves and electrochemical impedance spectroscopy showed good corrosion resistance. Work continues to tune the conditions for coating gloss as particular values are important for the different applications.

Author Contributions: Conceptualization and methodology: M.M.M., A.C.B., and M.G.S.F.; Investigation: M.M.M.; Writing—original draft preparation, review, and editing: M.M.M., R.M., A.C.B., A.M., P.O., J.T., and M.G.S.F.; Supervision: A.C.B. and M.G.S.F. All authors have read and agreed to the published version of the manuscript.

Funding: This research was funded by project ON-SURF-Mobilizar Competências Tecnológicas em Engenharia de Superfícies, Projeto n. ${ }^{\circ}$ POCI-01-0247-FEDER-024521.

Institutional Review Board Statement: Not applicable.

Informed Consent Statement: Not applicable.

Data Availability Statement: The data used to support the findings of this study are available from the correspondence authors upon request.

Acknowledgments: This work was developed within the scope of the project CICECO-Aveiro Institute of Materials, UIDB/50011/2020 and UIDP/50011/2020, financed by national funds through the Foundation for Science and Technology/MCTES. A.C.B. acknowledges FCT-Fundação para a Ciência e a Tecnologia, I.P., in the scope of the framework contract foreseen in the numbers 4,5 , and 6 of the article 23, of the Decree-Law 57/2016, of 29 August, changed by Law 57/2017, of 19 July. M.M.M. acknowledges FCT-Fundação para a Ciência e a Tecnologia for the scholarship (BPD-UA-A n'24521 ERDF).

Conflicts of Interest: The authors declare no conflict of interest. 


\section{References}

1. Lira-Cantu, M.; Sabio, A.M.; Brustenga, A.; Gómez-Romero, P. Electrochemical deposition of black nickel solar absorber coatings on stainless steel AISI316L for thermal solar cells. Sol. Energy Mater. Sol. Cells 2005, 87, 685-694. [CrossRef]

2. Wäckelgård, E. Characterization of black nickel solar absorber coatings electroplated in a nickel chlorine aqueous solution. Sol. Energy Mater. Sol. Cells 1998, 56, 35-44. [CrossRef]

3. Wernick, S.; Pinner, R. The Surface Treatment and Finishing of Aluminium and Its Alloys; Robert Draper Ltd: Teddington, UK, 1972; Volume 2.

4. Dennis, J.K.; Such, T.E. Nickel and Chromium Plating, 2nd ed.; Butterworth\&Co.: London, UK, 1986; pp. 48-50.

5. Ibrahim, M.A.M. Black nickel electrodeposition from a modified Watts bath. J. Appl. Electrochem. 2006, 36, 295. [CrossRef]

6. Karuppiah, N.; John, S.; Natarajan, S.; Sivan, V. Characterization of electrodeposited Nickel-Cobalt selective black coatings. Bull. Electrochem. 2002, 18, 295-298.

7. Aravinda, C.L.; Bera, P.; Jayaram, V.; Sharma, A.K.; Mayanna, S.M. Characterization of electrochemically deposited Cu-Ni black coatings. Mater. Res. Bull. 2002, 37, 397-405. [CrossRef]

8. Aravinda, C.L.; Mayanna, S.M.; Bera, P.; Jayaram, V.; Sharma, A.K. XPS and XAES investigations of electrochemically deposited cu-Ni solar selected black coatings on molybdenum substrate. J. Mater. Sci. Lett. 2002, 21, 205-208. [CrossRef]

9. Takadoum, J. Black coatings: A review. Eur. Phys. J. Appl. Phys. 2010, 52, 30401. [CrossRef]

10. Lelevic, A.; Walsh, F.C. Electrodeposition of Ni-P composite coatings: A review. Surf. Coat. Technol. 2019, 378, 124803. [CrossRef]

11. Gogna, P.K.; Chopra, K.L. Structure-dependent thermal and optical properties of black nickel coatings. Thin Solid Film. 1979, 57, 299-302. [CrossRef]

12. Lee, T.K.; Kim, D.H.; Auh, P.C. The optical characteristics of black chrome solar selective films coated by the pulse current electrolysis method. Sol. Energy Mater. Sol. Cells 1993, 29, 149-161. [CrossRef]

13. Popov, B.N.; White, R.E.; Slavkov, D.; Koneska, Z. Reduction of chromium (VI) when solar selective black chromium is deposited in the presence of organic additive. J. Electrochem. Soc. 1992, 139, 91. [CrossRef]

14. Gigandet, M.P.; Faucheu, J.; Tachez, M. Formation of black chromate conversion coatings on pure and zinc alloy electrolytic deposits: Role of the main constituents. Surf. Coat. Technol. 1997, 89, 285-291. [CrossRef]

15. Dubpernell, G. Electrodeposition of Chromium from Chromic Acid Solutions; Pergamon Press Inc.: New York, NY, USA, 1977. [CrossRef]

16. Kimbrough, D.E.; Cohen, Y.; Winer, A.M.; Creelman, L.; Mabuni, C. A Critical assessment of chromium in the environment. Crit. Rev. Environ. Sci. Technol. 1999, 29, 1-46. [CrossRef]

17. Pellerin, C.; Booker, S.M. Reflections on hexavalent chromium: Health hazards of an industrial heavyweight. Environ. Health Perspect. 2000, 108. [CrossRef] [PubMed]

18. Rahman, Z.; Singh, V.P. The relative impact of toxic heavy metals (THMs) (arsenic (As), cadmium (Cd), chromium (Cr)(VI), mercury $(\mathrm{Hg})$, and lead $(\mathrm{Pb}))$ on the total environment: An overview. Environ. Monit. Assess. 2019, 191, 419. [CrossRef]

19. Vaiopoulou, E.; Gikas, P. Regulations for chromium emissions to the aquatic environment in Europe and elsewhere. Chemosphere 2020, 254, 126876. [CrossRef]

20. Kalidhasan, S.; Kumar, A.S.K.; Rajesh, V.; Rajesh, N. The journey traversed in the remediation of hexavalent chromium and the road ahead toward greener alternatives-A perspective. Coord. Chem. Rev. 2016, 317, 157-166. [CrossRef]

21. Gharbi, O.; Thomas, S.; Smith, C.; Birbilis, N. Chromate replacement: What does the future hold? Mater. Degrad. 2018, 2, 12. [CrossRef]

22. Wilbur, S.; Abadin, H.; Fay, M.; Yu, D.; Tencza, B.; Ingerman, L.; Klotzbach, J.; James, S. Toxicological Profile for Chromium; Agency for Toxic Substances and Disease Registry (US): Atlanta, GA, USA, 2012.

23. World Health Organization. Chromium-Environmental Health Criteria $n^{\circ}$ 61; WHO: Geneva, Switzerland, 1988.

24. World Health Organization. Chapter 6.4-Chromium. In Air Quality Guidelines for Europe, 2nd ed.; European Series No. 91; WHO Regional Publications: Copenhagen, Denmark, 2001.

25. Von Burg, R.; Liu, D. Chromium and hexavalent chromium. J. Appl. Toxicol. 1993, 13, 225-230. [CrossRef]

26. Nunes, R.A.X.; Costa, V.C.; Sade, W.; Araújo, F.R.; Silva, G.M. Selective surfaces of black chromium for use in solar absorbers. Mater. Res. 2018, 21, e20170556. [CrossRef]

27. Patel, S.N.; Inal, O.T. Optimization and microstructural analysis of black-zinc-coated aluminum solar collector coatings. Thin Solid Film. 1984, 113, 47-57. [CrossRef]

28. Li, G.-Y.; Lian, J.-S.; Niu, L.-Y.; Jiang, Z.-H. A zinc and manganese phosphate coating on automobile iron castings. ISIJ Int. 2005, 45, 1326-1330. [CrossRef]

29. Jahan, F.; Islam, M.H.; Smith, B.E. Band gap and refractive index determination of Mo-black coatings using several techniques. Sol. Energy Mater. Sol. Cells 1995, 37, 283-293. [CrossRef]

30. Lizama-Tzec, F.I.; Macías, J.D.; Estrella-Gutiérrez, M.A.; Cahue-López, A.C.; Arés, O.; de Coss, R.; Alvarado-Gil, J.J.; Oskam, G. Electrodeposition and characterization of nanostructured black nickel selective absorber coatings for solar-thermal energy conversion. J. Mater. Sci. Mater. Electron. 2015, 26, 5553-5561. [CrossRef]

31. Li, X.J.; Cai, C.; Song, L.; Li, J.; Zhang, Z.; Xue, M.; Liu, Y. Electrodeposition and characterization of nano-structured black nickel thin films. Trans. Nonferrous Met. Soc. China 2013, 23, 2300-2306. [CrossRef]

32. Delaunois, F.; Vitry, V.; Bonin, L. (Eds.) Electroless Nickel Plating: Fundamentals to Applications, 1st ed.; CRC Press: Boca Raton, FL, USA, 2019. [CrossRef] 
33. Chappé, J.M.; Vaz, F.; Cunha, L.; Moura, C.; Marco de Lucas, M.C.; Imhoff, L.; Bourgeois, S.; Pierson, J.F. Development of dark $\mathrm{Ti}(\mathrm{C}, \mathrm{O}, \mathrm{N})$ coatings prepared by reactive sputtering. Surf. Coat. Technol. 2008, 203, 804-807. [CrossRef]

34. Andritschky, M.; Atfeh, M.; Pischow, K. Multilayered decorative a-C:H/CrC coating on stainless steel. Surf. Coat. Technol. 2009, 203, 952-956. [CrossRef]

35. Deutschen Normen. Galvanisierungsprüfung mit der Hull-Zelle, DIN50957; Deutsches Institut für Normung: Berlin, Germany, 1978.

36. Hull, R.O. Current density range characteristics-Their determination and application. Proc. Am. Electroplat. Soc. 1938, $27,52$.

37. I.O. for Standardization. Cross-cut test ISO 2409:2007. Br. Stand. Inst. 2013, 3, 9-11.

38. Estrella-Gutiérrez, M.A.; Lizama-Tzec, F.I.; Arés-Muzio, O.; Oskam, G. Influence of a metallic nickel interlayer on the performance of solar absorber coatings based on black nickel electrodeposited onto copper. Electrochim. Acta 2016, 213, 460-468. [CrossRef]

39. Orazem, M.E.; Tribollet, B. Electrochemical Impedance Specstroscopy, 2nd ed.; John Wiley \& Sons: Hoboken, NJ, USA, $2017 ;$ p. 395. 